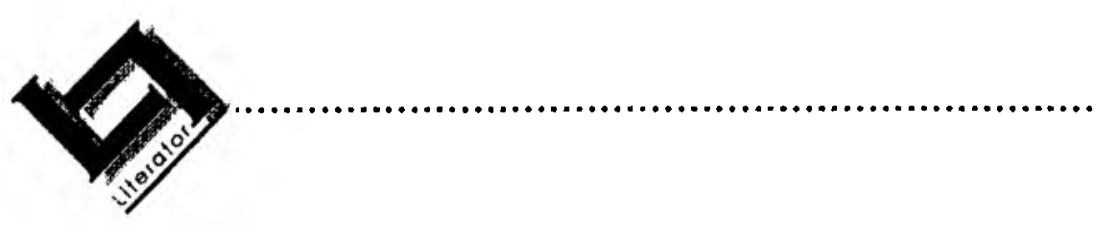

\title{
An approach to power relations: Bessie Head and Luisa Valenzuela ${ }^{1}$
}

\author{
Marita Wenzel \\ Department of English \\ Potchefstroom University for $\mathrm{CHE}$ \\ POICHEFSTROOM \\ E-mail: engm|w@puknet.puk.ac.za
}

\section{Abstract \\ An approach to power relations: Bessie Head and Luisa Valenzuela}

As authors and women writing within a postcolonial paradigm, Head and Valenzuela posit power relations as a prominent feature in their respective novels, $A$ Question of Power and Cola de Lagartija. These texts specifically expose the multi-layered scope of power relations and confirm the presence of such dynamics within the fabric of society and history. Different perpectives/voices represent the dynamics of social context as a series of power relations best interpreted by Bakhtin's perception of the dialogic principle operative in literature. In $A$ Question of Power and The Lizard's Tail, the abuse of power is challenged and exposed by the different narrators in their capacity as protagonists, narrators and authors. In this way they assert their powers as subjects, individuals, women; they gain a voice, an identity, and can proceed to make history as well as make history (in both the historical and literary sense). By writing, or perhaps reconceptualizing their past as individuals and writers, Head and Valenzuela have been enabled to forge their own future.

\section{Introduction: Liferature and meaning}

A comparison of two texts written by women from disparate countries and cultures, $A$ Question of Power (1994) by Bessie Head and Cola de Lagartija [The

I As this article is in English, I shall be quoting from the English translation of this text. 
Lizard's Tail] (1983) by Luisa Valenzuela, indicates a strong preoccupation with power relationships that are not only restricted to thematic concerns/content but also find expression in form and language. Although power relations feature prominently in the work of several authors writing within a postcolonial paradigm, especially women authors, Head and Valenzuela's novels specifically expose the multi-layered scope of the power relations that are embedded within the fabric of society and history. These authors' dependence on different perspectives/voices to represent the dynamics of social context and to express personal perceptions of political and social realities, is best interpreted by Bakhtin's understanding of the dialogic principle operative in literature. In $A$ Question of Power and The Lizard's Tail, the abuse of power constitutes the central theme that is challenged and exposed by the different narrators.

Bakhtin's dialogics emphasizes the sociological nature of a work of art/text and perceives its relationship to context as an essential element in the creation of meaning: "It becomes art only in the process of the interaction between creator and contemplator, as the essential factor in this interaction" (Bakhtin, 1989:597). Language represents an important component of this interaction as it is "both determining and determined by the historical components of particular utterances" (Bakhtin, 1989:593). In literature, the implicit value judgements in language relating to its original context are expressed through intonation or formal devices (Bakhtin, 1989:602/605) which play an important role in the "unmasking" of power relations. Pearce (1994:4) points out that intonation "may reinforce the apparent sincerity of a statement or, as in the case of irony, reveal a sentiment entirely at odds with it". Josephine Donovan (1991:85) also identifies style as an important subversive device in Bakhtin's repertoire as "literature exists in a political context and therefore literary devices reflect and refract the power differentials of the author's society". Consequently, as fictional autobiography and biography respectively, $A$ Question of Power and The Lizard's Tall represent self-conscious forms of narration that attribute the texts with additional interpretations of power.

Bakhtin claims that meaning is created by the interaction of three main participants in language utterances in different relations to each other (Bakhtin, 1989:603): they comprise the author (speaker), reader (listener) and the topic of speech. In this situation, the reader assumes the position of a listener who "must distinctly understand the positions of the other two participants" (Bakhtin, 1989:604). It is this process of interaction between language and context, and the polyphony of voices that characterizes feminist novels such as A Question of Power and Cola de Lagartija [The Lizard's Tail] and provides the occasion for irony. 


\section{Bakhtin and feminism}

Bakhtin never consciously acknowledged the feminist perspective (whether as author, narrator or character) ${ }^{2}$ as part of the polyphonic voices inherent in the novel, but his concept of the novel as a social construct and his recognition of the various power relations embedded in discourse, provide a suitable framework for a feminist interpretation and deconstruction of power relations. Patricia Yaeger (1991:240) stresses this correspondence and emphasizes the significance of a dialogic reading strategy in the exposition of ideological systems when she claims:

The narratives that we read are filled with power struggles in which some voices rise higher than others. The business of the dialogic imagination is to elicit these forbidden vocalities and show them at work. The business of a feminist dialogics is to gender these voices and to unmask the complex, contorted play of hegemonic forms and fermale speech - to explore the ways in which women from a variety of temporalities, ethnicities, races, and classes initiate dialogues with their oppressions.

With this framework in mind, I shall attempt to illustrate how A Question of Power and The Lizard's Tail relate to their specific socio-historic contexts and indicate how "the speakers of the word, either in life or in art, are located as socially marked in class, generational, professional and regional terms" (Dentith, 1995:48). In the above-mentioned texts, the main difference is located in gender/authority which is manifested in the novel as a dual or multiple perspective that undermines the authority of the narrator's voice and "grants equal authority to the word of the characters" (Dentith, 1995:42). This "doublevoiced discourse" (Dentith, 1995:48), which contests the issue of authority in the text, is not only restricted to intratextual relationships but also extends to author and reader, as Bauer and Mckinstry (1991:33) maintain when they refer to the various and conflicting discourses "between narrator and narratee, speaker and listener, character and character, and even (implied) author and (implied) reader". In Dentith's (1995:61) terms, Bakhtin perceives the novel as an example of active intervention in the social struggle "seeking to re-accent the other's word, to parody, subvert, overcome, accede to, or argue with that other word in multiple, different, but traceable ways". This subversive quality is especially prevalent in Bakhtin's notion of carnival, or the "principle of grotesque realism" (Dentith, 1995:67) that is manifested in ironic commentary and situation.

2 This fact could either be interpreted as conscious marginalization or unconscious integration. 
It is therefore the concept of polyphony in discourse and the revelation of power dynamics with its subsequent (and concomitant) subversive potential that I wish to identify and explore in A Question of Power and The Lizard's Tail.

\section{History and literature}

Both Head and Valenzuela conflate personal and "official" discourse by using historical events as points of departure in their fictional autobiographies/ biographies. It is the resultant dialectic between fiction and reality that constitutes the crux of the polyphonic voices in the above-mentioned novels. The specific choice of genre must be seen as a significant strategy here as Bakhtin (1995a:215) clearly stresses that self-conscious genres such as the confession, the diary, the biography

may not only enter the novel as one of its essential structural components, but may also determine the form of the novel as a whole (the novelconfession, the novel-diary, the novel-in-letters, etc.). Each of these genres possesses its own verbal and semantic forms for assimilating various aspects of reality. The novel, indeed, utilizes these genres precisely because of their capacity, as well-worked-out forms, to assimilate reality in words.

This approach emphasizes the role/voice of the individual as social being but inevitably also as part of history. It places the focus on identity and questions the validity of the master narrative/official history. A Question of Power can be read as a fictional autobiography of a period of mental instability in Bessie Head's life (as represented by Elizabeth) after her exile from South Africa, while The Lizard's Tail represents a "biographical novel" or a "novelized biography" - as Navoni, one of the characters, calls it (p. 187) - of López Rega, Isabel Perón's minister of Social Welfare during the political turmoil of the seventies. Both novels address the issue of power relations in dramatic and innovative ways to expose the different voices inherent in the discourse: for example, the constant interplay between the historic author and the author/narrator/biographer of the text as well as their interaction with the characters.

\section{A Question of Power}

In $A$ Question of Power, Elizabeth is the main protagonist/autobiographer but her mental conflict - precipitated by a mixed racial heritage, sexual and political oppression - is represented in the form of a dialogue with two distinctive male characters, Sello and Dan who, respectively, dominate the two main parts of the 
novel. Although represented as realistic contenders ${ }^{3}$ (with Elizabeth/Bessie Head as observer and locus of the conflict) Sello and Dan denote the different "voices" at war in Elizabeth/Bessie Head who attempts to come to terms with her traumatic past.

These voices represent the basic problems confronting Elizabeth: racial and gender discrimination. In the novel, she describes the effect of racial discrimination in South Africa as being similar to "living with permanent nervous tension" (p. 19), a condition also described by Tsitsi Dangarembga in her novel Nervous Conditions (1995). The intermittent references to her past experience in South Africa underline and explain this inherent tension in her personality. For instance, her awareness of racism is exploited by Medusa, Sello's partner, who forces her to recall that "In South Africa she had been rigidly classified Coloured. There was no escape from it to the simple joy of being a human being with a personality" (p. 44) and in a scene with Sello and Medusa, where they are discussing her life, a parallel is drawn to the fate of the Jews in Germany (p. 46). To recover from this trauma, she has to understand herself and recognize the forces at work in her life.

It is significant that "a major part of Elizabeth's inner struggle is directed against her feminine dependency, her fear and disgust of her own sexuality" (Kibera, 1991:317). She projects her secret fears and fantasies onto the figures of Sello and Dan who represent the forces of good and evil and who almost destroy her in their conflict for supremacy:

There seemed to be a mutual agreement in the beginning that an examination of inner hells was meant to end all hells forever. The pivot of the examination was Elizabeth. Both men flung unpleasant details at her in sustained ferocity. She had no time to examine her own hell (p. 12).

The conceptualization of conflicting male voices emphasizes the subversive quality of the discourse. Cary (1995:39) particularly distinguishes this feature in Head's work when he remarks: "Her nonfictional epistolary, autobiographical, and chronicle prose demonstrates her desire to undermine political, racial and religious singularity. Her fiction is polyphonic as well, presenting a variety of 'voices' in contention with one another".

Elizabeth is forced to identify the cause of her insecurity by reviewing and reassembling the fragments of her life. As the title of Sarvan's (1987:82) article

3 These characters could well pertain to the realm of magic realism. Mackenzie (1993:121) notes how the psychological struggle represented in the figures of Sello and Dan assumes a realistic dimension with "a certain narratological authority: they are, in fact, the very 'sturf of the text, the locus of the 'real life' of the novel". 
"A Question of Power and Identity" implies, power is closely related to identity. Elizabeth/Bessie Head has to experience a "nightmare soul-journey" (p. 35) in order to combat the hegemony of power. She also has to go through a process of self-evaluation which Henderson (1994:264) associates with black women writers, but which could also be applicable to Head, when she maintains:

One discovers in these writers a kind of internal dialogue reflecting an intrasubjective engagement with the intersubjective aspects of self, a dialectic neither repressing difference nor, for that matter, privileging identity, but rather expressing engagement with the social aspects of self ('the other[s] in ourselves').

It is significant that Elizabeth remains the onlooker, the voiceless victim exposed to her secret fears and revulsions and the focal point of the conflict. She is used by both Sello and Dan for their own selfish purposes and Caroline Rooney (1991:111) perceives her "to be the subjected or oppressed site where meanings are constructed, she is also the subjectless or effaced host of a parasitic deconstruction". It is only when she has come to terms with herself and her past that she can refuse being an object in the power game enacted by Sello and Dan and begin to construct her own future by writing it down.

Elizabeth's/Bessie Head's mental turmoil exposes male power as a manipulative personal/sexual and political tool which degrades the individual and relegates women to sexual objects. The mechanism of power is questioned and Elizabeth Bessie Head associates its effect with madness: "One would go stark, raving mad if a deep and endless endurance of suffering, such as one could encounter in Southem Africa, were really brought to the surface" (p. 83). Sarvan (1987:86) ascribes Elizabeth's (and indirectly Bessie Head's) ambivalent feelings towards emotional involvement and religious dogma as the reason for her problem with power, because "passion has power and is also therefore a force to be controlled". Consequently, power is perceived as a threat and Sello also formulates it as such when, near the end of the novel, he reminds Elizabeth of the scope of power: "I will never let you see it because I know what power does. If the things of the soul are really a question of power, then anyone in possession of the power of the spirit could be Lucifer" (p. 199 - original italics).

Within the context of an unfamiliar environment in Botswana and an alien and seemingly inhospitable people who practise social discrimination, Elizabeth/ Bessie Head almost loses her sanity. Although her (Elizabeths and Head's) past has made her reluctant to depend on people (Sarvan, 1987:85), her involvement in a gardening project and the forced acquaintance and interaction with the people concerned, help her to retain a tenuous link with reality:

It wasn't any kind of physical stamina that kept her going, but a vague, instinctive pattern of normal human decencies combined with the work she 
did, the people she met each day and the unfolding of a project with exciting inventive possibilities (p. 149).

Living in rapport with nature and the seasons seems to stabilize and give Elizabeth/Head a purpose in life (Kibera, 1991:317). She acquires the ability to adjust, find fulfilment in personal relationships for the first time and manages to transcend her feelings of inadequacy to become a maker instead of an observer/victim. She adapts like the Cape Gooseberry: "a complete stranger like the Cape Gooseberry settled down and became a part of the village of Motabeng" (p. 153). She finally manages to attain a voice, she belongs: "And then from the degradation and destruction of her life had arisen a still, lofty serenity of soul nothing could shake" (p. 202). Elizabeth's/Head's acknowledgement of her indebtedness to society becomes very significant when seen within the context of Bakhtin's tripartite notion of selfhood succinctly explained by Nealon (1997: 137):

Among the three selves that comprise subjectivity, only the I-for-others and the other-for-me can enjoy any kind of stability, and therefore it is only within the categories of outsidedness that the I-for-myself has any hope of realizing or stabilizing itself. The I-for-myself is, in other words, inexorably dependent on the others.

For Head, the vision of an "ideal human society" (Kibera, 1991:310) spells equality in all spheres of life, the personal as well as the political - Elizabeth indicates that she and Sello had "perfected together the ideal of sharing everything and then perfectly shared with all mankind" (p. 202). In order to attain this ultimate goal, Elizabeth/Head exposes the quality of human suffering caused by the abuse of power. However, she is careful to point out that such a situation not only affects the victim but also the perpetrator when she says in $A$ Question of Power:

The victim is really the most flexible, the most free person on earth. He doesn't have to think up endless laws and endless falsehoods. His jailer does that. His jailer creates the chains and the oppression. He is merely presented with it. He is presented with a thousand and one hells to live through, and he usually lives through them all. The faces of oppressed people are not ugly. They are scarred with suffering. But the torturers become more hideous day by day (p. 84).

Finally, Elizabeth's assumption of being the author of her own destiny, of creating her own history, is also transferred to the reader. Mackenzie (1993:122) identifies this aspect of the text when he claims that the author acts as a "conduit" for a polyphony of outside voices which require the reader's participation so that he/she is "encouraged to be a producer rather than a passive consumer of meaning". The reader then assumes a position similar to Elizabeth/Head in the 
text as an "author" and also takes responsibility for the outcome of the text as a maker of history.

\section{The Lizard's Tail}

Marie-Lise Gazarian Gautier (1986:105) aptly defines Valenzuela's writing as a "means to break barriers, to discover the various layers underneath visible reality, to remove masks, one by one, to come upon one's identity". Although Gazarian Gautier (1986:106) recognizes/intimates the significance of different styles and discourses at work in the novel, she mainly focuses on the "dynamic, almost parallel relationship between" the Sorcerer and the narrator/Luisa Valenzuela. Yet, it is also the conflict between various other voices such as author/reader and reader/character that define and reveal the true scope of power as a manipulative force.

The Lizard's Tail is not a traditional example of a biography because the position of "author" is actively contested by the biographer and the subject of the biography. This is already evident in the tripartite structure which, in the first section, is dominated by the Sorcerer as the male protagonist/third person narrator, in the second section, by the author (Valenzuela) as female biographer/ first person protagonist and again in the final and shortest section, by the Sorcerer. This distinctive way of identifying the different voices operative in a text also entails the direct involvement of the reader who has to assume the responsibility for judging the validity of the respective points of view represented.

Although the first half of The Lizard's Tail is devoted to the Sorcerer (López Rega), it is interspersed with other characters' points of view that undermine his assertions of grandeur. For example, in direct contrast to his perception of his own importance, he is alternately described by the government and the biographer as "dangerous", " poor lunatic" and a "clown" (p. 10).

The protagonist, or the Sorcerer as he is mostly called in the novel, ostensibly conducts a self-conscious monologue and his speech is, in fact, directed towards an audience of some kind because he expects some reaction to/confirmation of his self-praise - if not from the other characters/biographer/government, then from the reader. His self-aggrandizement implies a comparison of himself with other lesser mortals and he elevates himself to Biblical status (with a clearly parodic intent by the author/Valenzuela) when he says:

One ends up using other people's clichés as if one were like them, as if one could deal in human dimensions when impregnated by the infinite, the eternal, the all-encompassing. I am the Immanent, I am the salt of life (p. 3). 
The reader then perceives his speech as ironic when he then continues to assert: "That's how it is and I won't justify myself" (p. 3). I would suggest that this statement correlates with Bakhtin's (1995b:190) notion of self-conscious monologic discourse which implies "an ultimate word about oneself, a final definition of oneself, but in fact it is forever taking into account internally the responsive, contrary evaluation of oneself made by another". Nealon (1997:140) also asserts this principle when he states that "In a dialogic system, neither self nor other can live independently; while the self may be privileged, it can never be complete". The Sorcerer then makes this statement in anticipation of objections and attempts to circumvent them in this way.

A major part of the novel is also recounted from the perspective of the Sorcerer in the third person narrative form, for example, "Many females had tried to trap him. At one time he was a man of real power, a luscious mouthful" (p. 24). His constant preoccupation with sexuality and his third testicle which he calls his sister Estrella who must give birth to a son for him, is also a prevalent theme in the novel. It provides a good example of the grotesque element identified by Bakhtin (1995c:226) in Rabelais' work (which deals with exaggerated grotesque imagery in the descriptions of the giants Pantagruel and Gargantua):

This is why the essential role belongs to those parts of the grotesque body in which it outgrows its own self, transgressing its own body, in which it conceives a new, second body: the bowels and the phallus. These two areas play the leading role in the grotesque image, and it is precisely for this reason that they are predominantly subject to positive exaggeration, to hyperbolization; they can even detach themselves from the body and lead an independent life

The Government is secretly in collusion with the Sorcerer, ostensibly in the interests of National Reconstruction (p. 104), but in reality to reinforce its power base. This "partnership" is symbolized by the drug that the Sorcerer sells to the Government: it underlines the extent of the comuption and ruthless manipulation exerted on both sides. The Sorcerer regards himself as invincible (p. 277) and perceives the Government as a pawn in his game. When thwarted in any way, he simply removes the obstacles in his path - like General Durafiona - because he claims that "Doubt has to be eradicated by decree. There's no room for doubt in history" (p. 47). When the Sorcerer ironically uses the register for Government or official discourse, he underlines the essential duplicity of his own and their agenda.

The essential power wielded by the government is also symbolized by the title of the novel The Lizard's Tail. It is "a guarant term which refers to a type of whip that inflicts great pain and is used to punish" (Magnarelli, 1986:100) However, as Magnarelli (1986:100) aptly points out, it is not only associated with punish- 
ment, but also with the sinister and indestructible potency of power similar to the regenerative forces associated with a lizard's tail, a power that "may be broken or overthrown temporarily but which seems to regenerate spontaneously". In the third instance, it could also be seen as a phallic symbol (Magnarelli, 1986:101) denoting the cruelty of the Sorcerer.

The biographer (Valenzuela) and Navoni represent the opposition to the Government (in the text and Argentina). In contrast with the Sorcerer's mad monologue and affirmations of self-aggrandizement (perceived as such by the reader and the biographer but uttered in good faith by the Sorcerer himself), the biographer (Valenzuela) and Navoni's dialogue appears sane and reasonable. It is at this point that the dialogic occurs between the two or more voices. Although Navoni perceives the Sorcerer as a hypothetical danger, as a scapegoat for Government oppression - "A man who might not even exist, a man who's like the personification of collective hysteria and its undefined fears" (p. 34) - it is the biographer/Valenzuela, who appreciates the true psychological threat he poses. She senses that he is not inspired by either materialistic or political gain but by a personal gratification which knows no bounds or ethical/moral limits. He actually admits as much when he claims that "Power attracts me like few other things in the world, but I have no desire whatever for the obligations that power imposes" (p. 206). Consequently, the biographer/Valenzuela (p. 35) argues in the text:

We should analyze the elements that have been offered us point by point and deconstruct the textuality inscribed in the para-official discourse. We should try to structure our basic co-ordinates on the dichotomy of that governmental position. It's a perfect specular play: with a repressive superego on the surface (the government) and its repressive inverted image underground (the Sorcerer).

The biographer is under no illusion that the true enemy of the people is the government, as she states when she professes "I should try, as far as I can, to kill the military, who use him [the Sorcerer] as a justification, as a shield" (p. 199). This perception of "shield" also relates to the issues of masks which become important symbols of subterfuge. The Sorcerer not only serves as a mask for the government but he assumes the character of the government by callously torturing and killing people. By making the two indistinguishable, Valenzuela indirectly associates the government with a monster but, ironically, the Sorcerer's obvious pleasure in inventing outrageous torturing practices seems less sadistic than the

A situation similar to J.M Coetzee's novel Waiting for the Barbarians (1987). 
subterfuge practised by the government and the unknown fate of the people that have "disappeared" under its nule (p. 127) 5 .

Like the Government, the Sorcerer's power lies in his knowledge of the human psyche and his understanding of human greed: "... there will always be someone powerful like me to press others ... and use them for his very noble ends. Or for his dirty maneuvers. Whichever" (p. 98). He regards himself proudly as a maker of history, like the biographer/Valenzuela, and consequently threatens efface her self-imposed role as biographer when he states: “... for those who, like me, make history, inside and out, living it and telling it, justifying it and/or modifying it ... turning dreams into reality, passing from word to deed with complete impunity" (p. 105). Faced with this danger, Valenzuela has to assert herself and "assume responsibility for the story" because she knows that "he, too, is writing a novel that superimposes itself on this one and is capable of nullifying it" (p. 125). She inadvertently becomes part of the story and is "getting mixed up" in it (p. 127).

To the biographer/Valenzuela, writing is "the only possible way to counterattack" (p. 226) and she perceives the act of writing as similar to the power of witchcraft. By writing the biography of the Sorcerer she is entering his domain and subverting his power by shaping her account of the events - subverting the master narrative. She is well aware of the advantage of such an approach as she clearly states: "... why not combine his knowledge and my literary talents and achieve the true work that could well be this very same book?" (p. 221). In this sense, writing becomes an act of unmasking (Gazarian Gautier, 1986:106), of exposing the various power relations, of exorcising the ghost of fear as Navoni infers (p. 187). Or, as the biographer/Valenzuela in The Lizard's Tail claims: "A novelist is not in the world to do good but to try to know and transmit what is known; or is it to invent and transmit what is intuited?" (p. 129). It is an important exercise for the various characters concerned, for the biographer/ Valenzuela as well as the reader. As readers, we have to realize that the biographer is also a "guise" for the author Valenzuela who is exposing the various power relationships to actively involve the reader and raise his/her consciousness. The biographer/Valenzuela then raises a very important point when, in the beginning, she exclaims: "Why won't he die, I ask myself, why won't he just nicely jump into the lake. If the dog dies, the rabies might be cured. If the man disappears, all our troubles are over" (p. 34). She wants the reader to realize that the elimination of the Sorcerer will not resolve the abuse of power; violence is not

5 During the seventies, various countrics in Latin America experienced political upheaval due to military coups: Chile (1973), Uruguay (1973) and Argentina (1976). Any opposition to these authoritarian regimes resulted in people being unjustly imprisoned, tortured, exiled or simply eradicated without trace by the so-called desaparecidos. Francine Masiello (1992:1) mentions that betwcen 1976 and 1983, over 15,000 citizens had "disappeared" in Argentina. 
a resolution to oppression. It entails a pro-active deed of self-determination to counter such a threat

\section{Conclusion}

In both texts, Head and Valenzuela transcend the restrictions encountered in traditional discourse by asserting their powers as individuals, women and authors of their own texts: they gain a voice, an identity, and can proceed to make history as well as make history (in both the historical and literary sense). By writing, or perhaps re-conceptualizing their past as individuals and women/the oppressed, Head and Valenzuela have been enabled to forge their own future. While Elizabeth, thinly disguised as Bessie Head, writes a fictional autobiography of a psychological conflict populated by two male protagonists, the biographer/ Valenzuela composes a fictional biography of Lopez Rega in part but, for the most part also "allows" him to write his own autobiography. Both authors then allow the "oppressors" to disclose their lidden agendas while acting as observers. It is only when Head actively asserts herself to refute Sello and Dan's claims on her that she can recover her mental health and when Valenzuela takes a conscious decision to challenge the Sorcerer as protagonist and asserts her power as author to "erase" the Sorcerer by terminating his biography, that they both attain full potential. The act of writing then entails both a deconstructive and constructive dimension.

In conclusion, apart from gaining a perspective on the power relations prevalent in different societies/literary texts, I would hope that a comparison of the two texts has, as Ahearn and Weinstein (1995:79-80) claim, not only contributed towards a better understanding of the individual texts but has also reconfigured the "original" (or historical) texts to provide a new pattern or point of departure for discussions on these and other previously unassociated texts and make us, in Kadir's (1993:1) words, "other-wise"6 which could also be regarded as a key Bakhtivian concept.

\section{Bibliography}

Ahearn, E. \& Weinstein, A. 1995. The Function of Criticism at the Present Time: The Promise of Comparative Literature. In: Bernheimer, C. (ed) Comparative Literature in the Age of Multiculturallsm. Baltimore : Johns Hopkins University Press. p. 77-85.

Bakhtin, M.M. 1989. Discourse in Life and Discourse in Art (Concerning Sociological Poetics). In: Davis, Robert Con \& Finke, Laurie (eds.). Literary Criticism and Theory: The Greeks to the Present. New York : Longman. p. 594-613.

6 Kadir (1993:1) defincs this term as follows: "To be other-wise means to be wakeful to the othemess within as well as mindful of the other as other". 
Bakhtin, M.M. 1995a. Discourse in the Novel. In: Dentith, S. (ed). Bakhtinian Thought: An Introductory Reader. London : Routledge. p. 195-224.

Bakhtin, M.M. 1995b. The Hero's Monologic Discourse and Narrational Discourse in Dostoevsky's Short Novels. In: Dentith, S. (ed). Bakhtinian Thought: An Introductory Reader. London : Routledge. p. 157-194.

Bakhtin, M.M. 1995c. The Grotesque Image of the Body and its Sources. In: Dentith, S. (ed). Bakhtimian Thought: An Introductory Reader. London : Routledge. p. 225-253.

Bauer, Dale M. \& McKinstry, Susan Jaret (eds.). 1991. Feminism, Bakhtin, and the Dialogic. New York : State University of New York Press.

Cary, N.R. 1995. Religious Discourse in the Writing of Bessie Head: A Bakhtinian Reading. World Literature Written in English, 34(2):38-50

Coetzee, J.M. 1987. Waiting for the Barbarians. Harmondsworth : Penguin.

Dangarembga, Tsitsi. 1995. Nervous Conditions. London: The Women's Press.

Dentith, S. (ed.). 1995. Bakhtinian Thought: An Introductory Reader. London : Routledge.

Donovan, Josephine. 1991. Style and Power. In: Bauer, Dale M. \& McKinstry, Susan Jaret (eds ). Feminism, Bakhtin, and the Dialogic. New York : State University of New York Press. p. 85-94.

Gazarian Gautier, Marie-Lise. 1986. The Sorcerer and Luisa Valenzuela: Double Narrators of the Novel/Biography, Myth/History. The Review of Contemporary Fiction, 6(3):105108.

Head, Bessie. 1974. A Question of Power. Oxford : Heinemann.

Henderson, Mae Gwendolyn. 1994. Speaking in Tongues: Dialogics and the Black Woman Writer's Literary Tradition. In: Williams, P. \& Chrisman, Laura (eds.). Colonial Discourse and Post-Colonial Theory: A Reader. New York : Columbia University Press. p. 257-267.

Kadir, D. 1993. The Other Writing: Postcolonial Essays in Latin America's Writing Culture. West Lafayette : Purdue University Press.

Kibera, Valerie. 1991. Adopted Motherlands: The Novels of Marjorie Macgoye and Bessie Head. In: Nasta, Susheila (ed.). Motherlands: Black Women's Writing from Africa, the Caribbean and South Asia. London: The Women's Press. p. 310-329.

Mackenzie, C. 1993. Allegiance and Alienation in the Novels of Bessie Head. In: Gurnah, A. (ed). Essays on African Writing: A Re-Evaluation. Oxford : Heinemann. p. 111-125.

Magnarelli, Sharon. 1986. The Lizard's Tail: Discourse Denatured. The Review of Contemporary Fiction, 6(3);97-104.

Masiello, Francine. 1992. Between Civilization and Barbarism: Women, Nation, and Literary Culture in Modern Argentina. Lincoln : University of Nebraska Press.

Nealon, J.T. 1997. The Ethics of Dialogue: Bakhtin and Levinas. College English, 59(2): 129-148.

Pearce, Lynne. 1994. Reading Dialogics. London : Edward Amold.

Rooney, Caroline. 1991. Dangerous Knowledge and the Poetics of Survival: A Reading of Our Sister Killjoy and A Question of Power. In: Nasta, Susheila (ed.). Motherlands: Black Women's Writing from Africa, the Caribbean and South Asia. London: The Women's Press. p. 299-326.

Sarvan, C.P. 1987. Bessie Head: A Question of Power and Identity. In: Durosimi, Eldred (ed ). Women in African Literature Today: A Review. London : James Currey. p. 8288.

Valenzuela, Luisa. [1983] 1987. The Lizard's Tail. Trans. G. Rabassa. London : Serpent's Tail. 
Yaeger, Patricia. 1991. Afterword. In: Feminism, Bakhtin, and the Dialogic. In: Bauer, Dale M. \& McKinstry, Susan Jaret (eds.). New York : State University of New York Press. p. 239-245. 